\title{
Towards Added Value Attieke Production in Côte d'Ivoire Using Bacillus spp. as Starters
}

\author{
Ayawovi Ehon, Regina Krabi, Antoine Assamoi, Sébastien Niamké*
}

Laboratoire de Biotechnologies, Filière Biochimie-Microbiologie, Unité de Formation et de Recherche en Biosciences, Université Félix Houphouët-Boigny, Abidjan, Côte d'Ivoire. 22 BP 582 Abidjan 22

A R T I C L E I N F O

Article history:

Received 05 April 2016

Accepted 27 October 2016

Available online, ISSN: 2148-127X

Keywords.

Bacillus spp.

Technological properties

Attiéké

Standardization

Cassava

* Corresponding Author:

E-mail: niamkes@yahoo.fr

\section{A B S T R A C T}

In Côte d'Ivoire, the most fermented cassava food product is "attiéké". Various microorganisms involved in this fermentation process. Bacillus spp. are well-known for their multi-potential enzymatic activities. In this study, Bacillus spp. strains were studied for their ability of growing in environmental stress as follow: $\mathrm{NaCl}$ ( 2 to $9 \%$ ) and lactic acid $(0.1$ to $1 \%)$. The growth of the studied strains was inhibited at $5 \%$ (1 strain), $7 \%$ (2 strains) and $8 \%$ (7 strains) for $\mathrm{NaCl}$ and beyond $0.25 \%$ for lactic acid. The ability of the isolated Bacillus strains to ferment cassava dough for "attiéké" production was also tested. The results of sensory tests showed that "attiéké" produced with Bacillus spp. strains was quite similar to "attiéké" control (traditional "attiéké") except for the brilliance and granulation for which the control obtained the highest scores. The present research indicated that cassava dough fermentation, initiated by the inoculation of Bacillus strains associated with or without lactic acid bacteria should be useful to improve and standardize the quality of "attiéké" produced in Côte d'Ivoire.

\section{Introduction}

Cassava (Manihot esculenta Crantz) is among the most important root crops in the world by providing food for one billion people (Bokanga, 2001; FAO, 2008).Cassava roots are often subjected to fermentation processing before consumption and various fermented cassava products are available; these are: "gari", "foofoo", "lafun", "attiéké", etc (Obadina et al., 2009; Coulin et al., 2006). In Côte d'Ivoire, the most popular fermented cassava food is "attiéké" defined as steamed semolina (Assanvo et al., 2002; Dje et al., 2008). The food "attiéké" is consumed two to three times a day in combination with meat, fish or vegetables and this food is one of the main generating of monetary incomes for producers (Toka et al., 2008; Djeni et al., 2011). According to Aboua et al. (1990), the total consumption of Ivorian population is about 28,000 to 34,000 tons of "attiéké" per year which represents the equivalent of 40,000 to 50,000 tons of fresh cassava. Despite this economical and nutritional importance, , the preparation of "attiéké" by women is still an informal activity mainly based on their traditional experience and not on a rational knowledge (Essers et al., 1993; Fortin et al., 1998; Mosso et al., 2000). The processing of cassava roots into "attiéké" involves the following steps: peeling, cutting, washing and grating. During grating step, the cassava dough is mixed with $10 \%$ of a traditionally prepared microorganisms inoculum called "mangnan" and $0.1 \%$ of palm oil. This inoculum was previously prepared by the storage of boiled cassava roots for three days of natural fermentation in unwashed jute bag. The inoculated cassava pulp is then fermented overnight in covered bins. Afterwards, the fermented pulp is filled into bags and pressed for several hours in order to drain the liquid phase. The remaining press cake is removed from the bags and squeezed through a sieve to obtain granules that are sun-dried and then cleaned to take out fibers and wastes. The dried granules are finally steamed in order to produce "attiéké" (Coulin, 2004). It is important underlying that the traditional inoculum used for "attiéké" production consists of a wide variety of microorganisms (lactic acid bacteria, Bacillus spp., yeasts and moulds) which constitutes the main source of microbial activities during the cassava dough fermentation (Coulin et al., 2006; Djeni et al., 2008). Among these microorganisms, Bacillus spp. produces different enzymes that detoxify and soften cassava dough (Bouatenin et al., 2012). Moreover Bacillus spp. can grow in slightly acidic medium and resist to other environmental stress factors (Coulin et al., 2006; Kumar et al., 2013). Some species of Bacillus could also produce lactic acid (Rosenberg et al., 2005; Ouyang et al., 2013) which may give to "attiéké" an acidulous taste. Therefore, an extensive description of the 
microbial diversity of cassava dough appears as prerequisite for the development of starter cultures to improve the indigenous processing. This description should include the biochemical identification of the representative microorganisms (Miambi et al., 2003). This would justify the scientific efforts going towards the development of starters containing high concentrations of living microorganisms, in order to ensure the regularity and stability of the final product (Yao et al., 2013). Thus, the aim of this study is to search out Bacillus strains possessing interesting technological properties which could be used as starter cultures in order to control and standardize the fermentation of cassava dough for producing "attiéké" with good quality.

\section{Material and Methods}

\section{Samples Collection, Bacillus Identification and Enzymes Production}

Traditional cassava starters ("mangnan") were collected from 11 manufacturing units in the District of Abidjan (Koumassi, Abobo, Marcory, Attécoubé, PortBouet, Treichville, Adjamé, Yopougon, Cocody, Bingerville and Anyama) and from 3 areas (Bassam, Dabou and Jacqueville) located in peri-urban areas of this District. Bacillus spp. strains were isolated after an enrichment step described as follow: $10 \mathrm{~g}$ of different samples were diluted in $90 \mathrm{~mL}$ of sterile buffer peptone water and incubated at $30^{\circ} \mathrm{C}$ during $18 \mathrm{~h}$. The medium was then heat in water bath at $80^{\circ} \mathrm{C}$ for $10 \mathrm{~min}$ in order to select spore forming bacteria on nutrient agar (Scharlau). Concerning Bacillus spp. identification, morphological and biochemical characterization of isolates were performed by Gram staining and catalase tests. For motility test, each colony was sub-cultured in brain-heartbroth medium at $30^{\circ} \mathrm{C}$ for $4 \mathrm{~h}$. For enzymes production such as amylase, pectinase, cellulase and phytase, the tests were carried out using the method described by Ouattara et al.(2008); while for production of $\beta$ glucosidase enzymes, the method described by Weagant et al. (2001) was performed.

Effects of Environmental Factors Stress on The Growth Parameters of Bacillus Spp.

Effect of temperature: Different strains were purified on nutrient agar (Scharlau) and inoculated in nutrient both containing $1 \%$ of glucose (Scharlau). Then, $100 \mu \mathrm{L}$ of pre-culture $\left(\mathrm{OD}_{600}=1\right)$ was used to inoculate $5 \mathrm{~mL}$ of the same broth. The medium was incubated at various temperatures $\left(30^{\circ} \mathrm{C} ; 37^{\circ} \mathrm{C} ; 45^{\circ} \mathrm{C}\right.$ and $\left.55^{\circ} \mathrm{C}\right)$ for $18 \mathrm{~h}$. After incubation, the optical density (OD) was recorded at 600 $\mathrm{nm}$ to determine the optimum growth temperature.

Effect of $\mathrm{NaCl}$, Lactic acid and $\mathrm{pH}$ : The response of Bacillus spp. strains to the osmotic and acid stress induced by $\mathrm{NaCl}$ and lactic acid was carried out using the method described by Sow (2004). The broth medium containing $2 \%$ of glucose, $1 \%$ of yeast extract and $1 \%$ of casein pepton (Oxoid) was supplemented with different concentrations of $\mathrm{NaCl}(2 ; 3 ; 4 ; 5 ; 7$ and $9 \%)$ and lactic acid $(0.1 ; 0.2 ; 0.25 ; 0.75$ and $1 \%)$. A pre-culture was made in medium broth and was incubated at $37^{\circ} \mathrm{C}$ for 16 h. $100 \mu \mathrm{L}$ of the pre-culture $(\mathrm{OD}=1$ at $600 \mathrm{~nm})$ were used to inoculate $5 \mathrm{~mL}$ of the medium mentioned above. Then, a medium was incubated at $37^{\circ} \mathrm{C}$ for $18 \mathrm{~h}$ and the bacterial growth was recorded by reading the OD at 600 $\mathrm{nm}$. To evaluate the influence of $\mathrm{pH}$ on microbial growth, the same method mentioned above was performed for different $\mathrm{pH}$ values: $3 ; 4 ; 5 ; 7 ; 9$ and 11 .

\section{Lactic Acid Production}

For lactic acid production, the Bacillus spp. strains were pre-cultured in nutrient broth (Scharlau) containing $1 \%$ of glucose (Scharlau). Two reference strains of lactic acid bacteria: lactobacillus plantarum W1582 and W 1366 (Centre for Industrial Microbiology, Gembloux, Belgium) were tested to compare their performance in Man Rogosa and Sharpe (MRS) medium (Scharlau) at $37^{\circ} \mathrm{C}$ for $16 \mathrm{~h}$ and $\mathrm{pH} 7$. After incubation, $100 \mu \mathrm{L}$ of the pre-culture $(\mathrm{OD}=1$ at $600 \mathrm{~nm})$ were used to inoculate 5 $\mathrm{mL}$ of the broth medium $(\mathrm{pH}=7)$ mentioned above. The mixture obtained was centrifuged for $15 \mathrm{~min}$ at 4,000 rpm and the supernatant was titrated with a solution of $\mathrm{NaOH}$ $(0.1 \mathrm{~N})$, using phenolphthalein as indicator. The total titratable acidity was calculated as a percentage of lactic acid.

\section{Laboratory-Scale of "Attiéké" Production}

Following the previous studies of the environmental stress and lactic acid production, 5 potential Bacillus strains were selected for cassava dough fermentation into "attiéké" production.

Inoculum preparation: One hundred and fifty grams $(150 \mathrm{~g})$ of cassava mash were inoculated with $10^{8} \mathrm{CFU} / \mathrm{g}$ of Bacillus spp. strains. The resulting mixture was incubated at $30^{\circ} \mathrm{C}$ for $24 \mathrm{~h}$. Concerning the preparation of traditional "attiéké" (control), the traditional inoculum (mangnan) was used.

Fermentation of cassava dough: After grinding of cassava roots, the dough was portioned into six different sterile plastic bags. The different portions of cassava dough were inoculated with the starter culture of Bacillus spp. and incubated at $30^{\circ} \mathrm{C}$ for $12 \mathrm{~h}$. After incubation, the fermented cassava dough was pressed with a manual screw press, to remove water. The press cake, was sieved on a synthetic sieve, in order to remove thick fibers and pieces of pulp insufficiently ground. The powdery mass was then granulated during 20 minutes into grains similar to semolina. The grains were dried in the sun and the cassava semolina was steamed to obtain "attiéké".

\section{Total Titratable Acidity}

Total titratable acidity was determined according to the method described by Nout et al. (1989). Ten (10) grams of each sample (fermented cassava dough and "attiéké") were diluted in $90 \mathrm{~mL}$ of distilled water and filtered through a Whatman filter paper. $10 \mathrm{~mL}$ of the filtrate was titrated with $\mathrm{NaOH}\left(\begin{array}{ll}0.1 & \mathrm{~N}\end{array}\right)$ using phenolphthalein as indicator; the total titratable acidity is given by the following formula: 


$$
\mathrm{TTA}=\frac{\mathrm{V}_{\mathrm{b}} \times \mathrm{N}_{\mathrm{b}} \times 0.09 \times 100}{\mathrm{~V}_{\mathrm{f}}}
$$

TTA $=$ Total titratable acidity $(\%)$

$\mathrm{V}_{\mathrm{b}} \quad=$ Volume of the basic solution $(\mathrm{mL})$;

$\mathrm{N}_{\mathrm{b}} \quad$ = Normality of basic solution;

0.09 = Conversion factor for lactic acid;

$\mathrm{V}_{\mathrm{f}} \quad=$ Volume of filtrate $(\mathrm{mL})$.

\section{pH Determination}

The determination of $\mathrm{pH}$ was carried out according to the protocol described by Nout et al. (1989). Ten (10) grams of each sample were mixed with $20 \mathrm{~mL}$ of sterile distilled water. The mixture obtained was filtered through a Whatman filter paper. The $\mathrm{pH}$ was then recorded by using a pH meter (Hanna HI 2223).

\section{Sensory Analysis}

Sensorial quality attributes of the different "attiéké" samples were evaluated using distinguishing parameters such as, colour, brilliance, graininess, presence of fibers, aroma, texture, odor, sourness and sweetness. Ten (10) trained panelists were chosen to determine the general acceptability of "attiéké" produced. A sensorial profile was done by a 9- point hedonic rating scale based on the different degrees of acceptability of the product. This profile was conducted with scores ranging by ' 9 ' (having excellent characteristic) to ' 1 ' (very weak characteristic) for the attributes description.

\section{Statistical analysis}

Experiments were conducted in triplicate and the results were expressed as mean $\pm \mathrm{SD}$. The results were also subjected to analysis of variance (ANOVA) and differences between means were assessed by Duncan multiple range tests at the significance defined at $\mathrm{P} \leq$ 0.05, using SPSS 18.0 software and Excel 2007.

\section{Results}

\section{Bacillus Identification and Enzymes Production}

A total of 141 Bacillus strains were isolated from the traditional "mangnan". Among these, 10 strains characterized by interesting enzymatic properties were subjected to the effects of environmental stress and the production of lactic acid. The enzymatic properties of Bacillus strains used for cassava dough fermentation are summarized in Table 1.

\section{Effect of Temperature}

The growth curves of the 10 Bacillus strains subjected to various incubation temperatures are presented in Figure 1. The selected Bacillus strains had their optimum growth at $37^{\circ} \mathrm{C}$, unlike the Bacillus strains Bas 13 and 103, which had their optimum growth at $45^{\circ} \mathrm{C}$. The stabilization of the growth curve was observed at $55^{\circ} \mathrm{C}$. Concerning Bacillus strain Bas 58, a decrease of its growth rate was observed at $45^{\circ} \mathrm{C}$

\section{Effect of $\mathrm{NaCl}$ Concentration}

The growth of Bacillus strains decreased with the increasing of $\mathrm{NaCl}$ concentration in the medium. For $5 \%$ of $\mathrm{NaCl}$ concentration, none growth was observed for the strain Bas 13. Furthermore the growth of Bas 99 and 102 was not observed for $7 \%$ of $\mathrm{NaCl}$ concentration. Also, for the other Bacillus strains (Bas 4; 18; 57; 58; 66; 97and107), their growth was inhibited at $8 \%$ of $\mathrm{NaCl}$ concentration (Figure 2).

\section{Effect of Lactic Acid Concentration}

The increasing of lactic acid concentration (0.1 to $1 \%)$ caused a decrease of Bacillus spp. growth rate, followed by inhibition. The growth of Bacillus (Bas 57 and 58) was inhibited for $0.25 \%$ of lactic acid concentration, whereas the growth of the other isolates, was inhibited for a concentration grater than $0.25 \%(0.25 \%$ to $1 \%)$ (Figure 3$)$.

\section{Effect of $p H$}

For $\mathrm{pH}$ values between 3 and 4 , it was observed a slowdown of microbial growth. Beyond $\mathrm{pH} 4$, an increasing of growth rate was observed up to a maximum of $\mathrm{pH} 7$ for Bacillus strains (Bas 18; 57; 58; 66; 97; 99; 102 and 107). In addition, Bas 4 and 13 reached their maximum growth for $\mathrm{pH}$ values of 8 and 9 . Beyond the values of $\mathrm{pH} \mathrm{7,8}$ and 9 , a decline of the microbial growth was observed for all the tested strains (Figure 4).

Table 1 Enzymatic properties of isolated Bacillus spp. strains

\begin{tabular}{|c|c|c|c|c|c|}
\hline Strains & Amylase & Pectinase & Cellulase & Phytase & $\beta$ - glucosidase \\
\hline Bas 4 & +++ & +++ & +++ & +++ & ++ \\
\hline Bas 18 & ++ & +++ & ++ & ++ & ++ \\
\hline Bas 13 & +++ & +++ & ++ & ++ & - \\
\hline Bas 57 & ++ & +++ & ++ & ++ & ++ \\
\hline Bas 102 & ++ & +++ & ++ & +++ & +++ \\
\hline Bas 58 & ++ & +++ & ++ & ++ & +++ \\
\hline Bas 66 & ++ & +++ & ++ & ++ & +++ \\
\hline Bas 107 & ++ & ++ & ++ & +++ & - \\
\hline Bas 97 & ++ & ++ & +++ & +++ & ++ \\
\hline Bas 99 & +++ & +++ & +++ & +++ & +++ \\
\hline
\end{tabular}




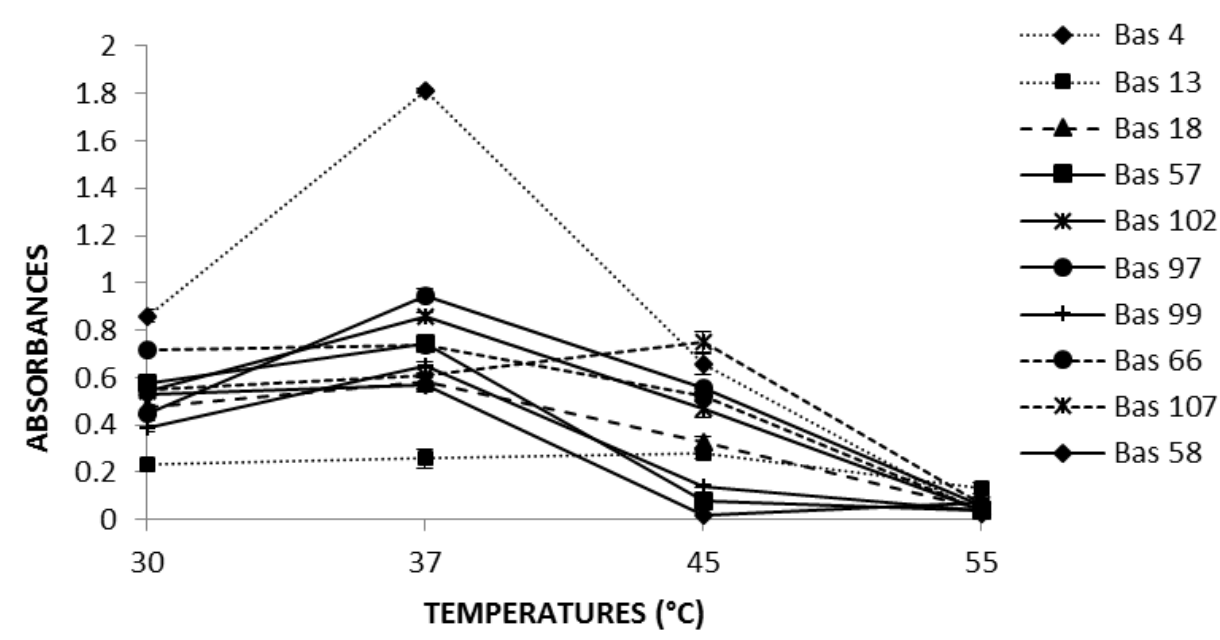

Figure 1 Effect of temperature on Bacillus strains growth. The observation is a mean of 3 replicate experiments $(\mathrm{n}=3)$

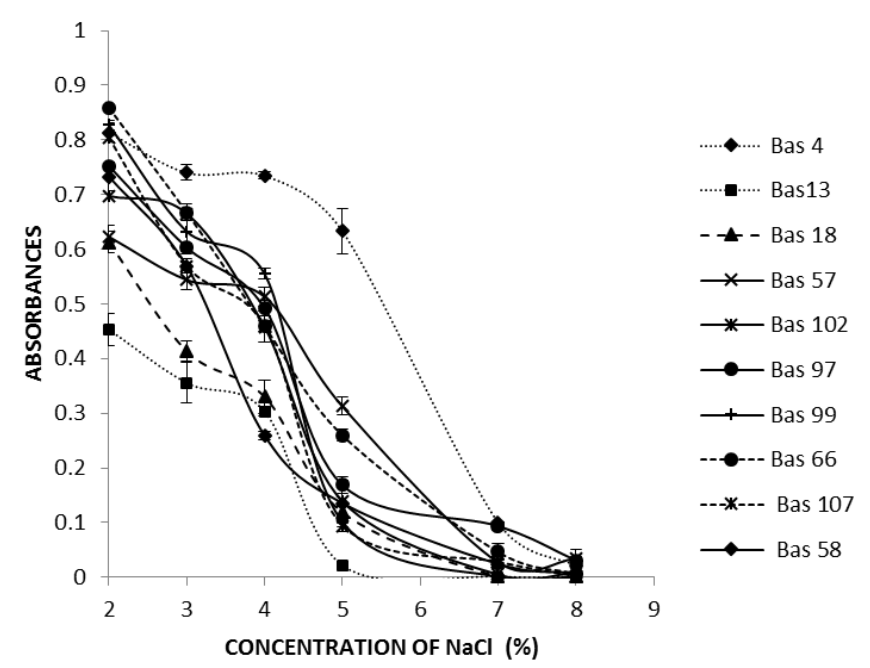

Figure 2 Effect of $\mathrm{NaCl}$ concentration on Bacillus strains growth. The observation is a mean of 3 replicate experiments $(n=3)$

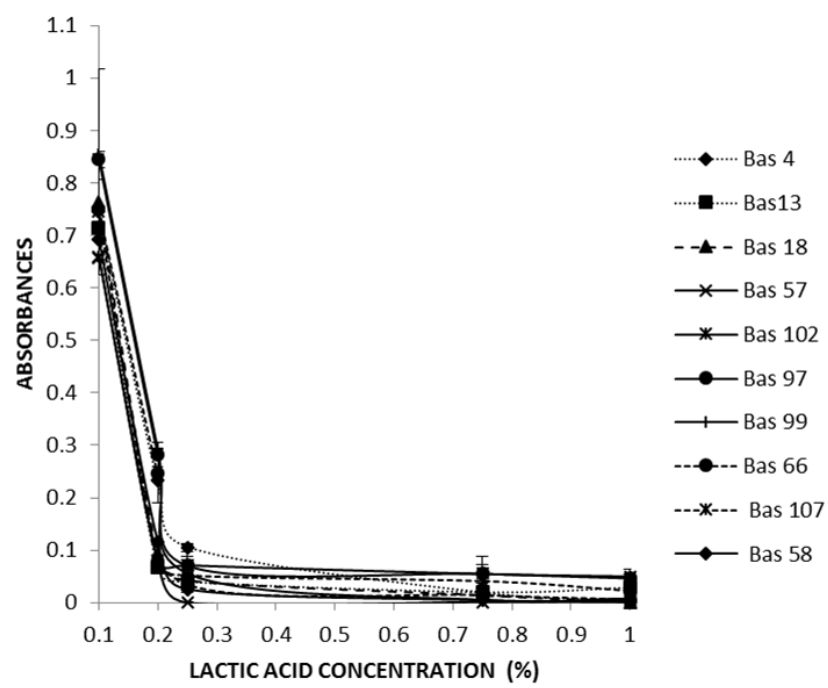

Figure 3 Effect of lactic acid concentration on Bacillus strains growth. The observation is a mean of 3 replicate experiments $(\mathrm{n}=3)$ 


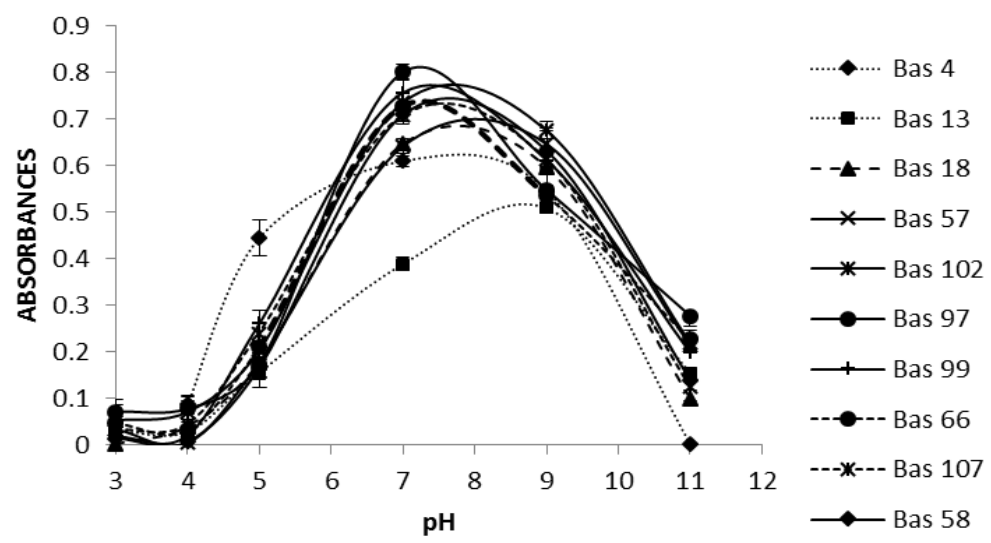

Figure 4 Effect of $\mathrm{pH}$ variation on Bacillus strains growth. The observation is a mean of 3 replicate experiments $(\mathrm{n}=3)$

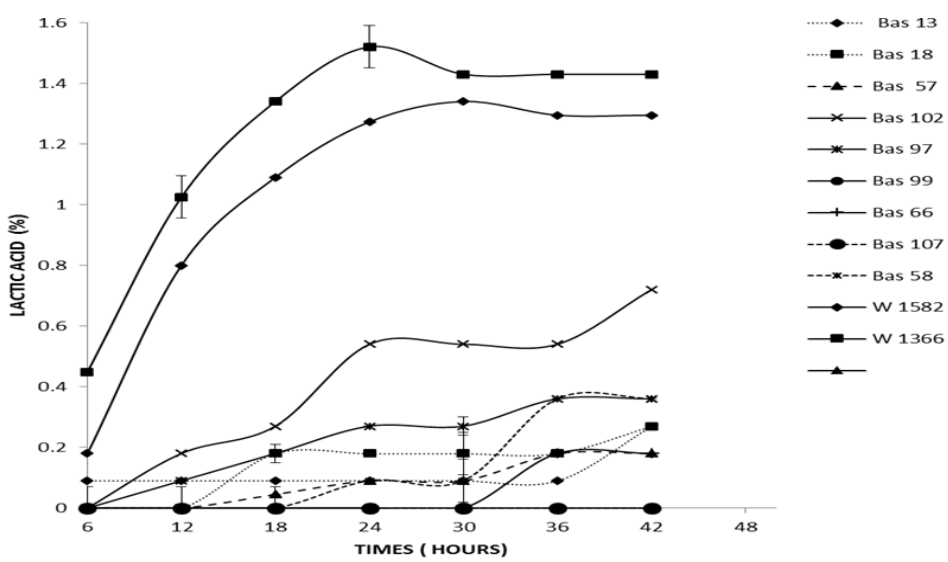

Figure 5 Lactic acid production of microbial strains. The observation is a mean of 3 replicate experiments $(n=3)$

\section{Lactic Acid Production}

Two strains of lactic acid bacteria (lactobacillus plantarum $\mathrm{W} 1582$ and $\mathrm{W} 1366$ ) produced a great quantity of lactic acid in comparison with Bacillus strains. Only Bas 102 produced 0.18 to $0.54 \%$ of lactic acid during $24 \mathrm{~h}$ of incubation (Figure 5).

\section{Total Titratable Acidity and $p H$}

The different $\mathrm{pH}$ values for fermented cassava pulps inoculated with Bacillus spp. strains decreased after 12 hours. Also, the $\mathrm{pH}$ values of different samples of "attiéké" obtained with Bacillus spp. strains (Bas 4, Bas 58, Bas 66, Bas 97 and Bas 102) had a lower $\mathrm{pH}$ compared to the control (Table 2).

\section{Sensory Test}

Sensory test for "attiéké" produced by using the different Bacillus strains (Bas 4, Bas 58, Bas 66, Bas 97 and Bas 102) as starters was judged slightly similar to the control. Nevertheless the control one had a better brilliance, contained less fibers and more rounded grains. For the brilliance, "attiéké" control obtained the highest score of 3.95 compared to the scores (2.9 to 3.5) of "attiéké" produced with Bacillus spp. The tested "attiéké" control had the best graininess and acidulous taste scores (6.95 and 3.95) and contained less fibers (score of 2.95 against scores ranged from 3.2 to 4.05 for "attiéké" produced with Bacillus strains) (Figure 6).

\section{Discussion}

The presence of Bacillus spp. strains in fermented cassava dough was reported by several studies (Assanvo et al., 2002; Coulin et al., 2006; Bouatenin et al., 2012). These bacterial species are very important because they produce different enzymes which contribute to the softness and detoxification of cassava dough (Bouatenin et al., 2012). Concerning their growth at different temperatures, all strains had their optimal growth at $37^{\circ} \mathrm{C}$, except the strains Bas 13 and Bas 107 which had their optimum growth at $45^{\circ} \mathrm{C}$. This result is not surprising, because the studied Bacillus spp. strains have been isolated from "mangnan", prepared at ambient temperature $\left(28\right.$ to $35^{\circ} \mathrm{C}$ ) (Assanvo et al., 2002). According to Dje et al. (2008), the optimum temperature of cassava dough during fermentation for "attiéké" production is $35^{\circ} \mathrm{C}$. Therefore, the Bacillus strains could easily evolved in fermented cassava dough for the production of "attiéké". The growth of Bacillus strains was inhibited for 5\% (1 strain), 7\% (2 strains) and 8\% (7 stains) of $\mathrm{NaCl}$ concentrations. Indeed, the presence of $\mathrm{NaCl}$ in the medium constitutes an osmotic stress (Obilie et al., 2003) and this enables Bacillus spp. strains to synthesize several organic compounds such as betain; trehalose; glycin; camitine; proline for maintaining their vital functions in order to protect themselves (Sow, 2004).

Concerning the influence of lactic acid concentration, the growth of all the strains was inhibited beyond $0.25 \%$ 
of lactic acid, contrary to the studies conducted by Coulin et al. (2006), where the strains of Bacillus spp. had their growth for more than $0.3 \%$ of lactic acid. From this point of view, our isolated strains would be able to show metabolic activities in a fermentation medium with lactic acid concentration lower than $0.25 \%$.

For lactic acid production, Lactobacillus plantarum, is well-known to produce a great quantity of lactic acid in a fermentation medium. Indeed, Oyewole (1992), reported that Lactobacillus plantarum strain is associated with high acid lactic production during cassava fermentation for "foofoo" production. Concerning "attiéké" production, the lactic acid bacteria play also an important role in acidification by lactic acid production (Coulin et al., 2006). But, the capacity to produce lactic acid was also observed for Bacillus strains in fermentation medium (Penga et al., 2013; Ouyang et al., 2013). According to Poudel et al. (2015), Bacillus spp. can produce lactic acid as observed with Bacillus thermoamylovorans which has ability to ferment starch for lactic acid production. The lactic acid production by Bacillus spp. would be useful during of the fermentation of cassava dough, because the of the acidification step which determines the final acidulous taste of "attiéké". For instance, the Bacillus strains Bas 102 produced a great quantity of lactic acid (0.18 to $0.54 \%$ ) showing higher performance than the Bacillus spp strains. studied by Bouatenin et al. (2012). For the in vitro test of cassava dough fermentation, the concentration of Bacillus $\left(10^{8} \mathrm{CFU} / \mathrm{g}\right)$ was used according to the maximum level of Bacillus contained in the traditional starter (mangnan) (Assanvo et al., 2006). This traditional starter (mangnan) had a better acidification rate of cassava dough compared to that obtained with Bacillus strains, because traditional starter contains several microorganisms which are mostly lactic acid bacteria. According to Sotomey et al. (2001), the $\mathrm{pH}$ value of traditional cassava dough after $12 \mathrm{~h}$ of fermentation is 4.61. In this study, the $\mathrm{pH}$ value of traditional cassava dough for the same duration of fermentation was 4.13. In addition, our results showed that the $\mathrm{pH}$ value obtained after $12 \mathrm{~h}$ of cassava dough fermented with the selected Bacillus strains was slightly lower than that obtained with traditional starter (mangnan) for the same time.

Table $2 \mathrm{pH}$ values and total titratable acidity of cassava dough and "attiéké"

\begin{tabular}{l|ll}
\multicolumn{1}{c|}{ Sample } & \multicolumn{1}{c}{$\mathrm{pH}$} & \multicolumn{1}{c}{ Total titratable acidity (\%) } \\
\hline Pulp after grating (pulp without strains tested) & $6.37^{\mathrm{d}} \pm 0.14$ & $0.18^{\mathrm{a}} \pm 0.00$ \\
Pulp after 12 h fermentation with Bas 4 & $4.20^{\mathrm{ab}} \pm 0.03$ & $0.52^{\mathrm{b}} \pm 0.14$ \\
Pulp after 12 h fermentation with Bas 58 & $4.32^{\mathrm{bc}} \pm 0.12$ & $0.5^{\mathrm{b}} \pm 0.21$ \\
Pulp after 12 h fermentation with Bas 66 & $4.2^{\mathrm{ab}} \pm 0.04$ & $0.52^{\mathrm{b}} \pm 0.19$ \\
Pulp after 12 h fermentation with Bas 97 & $4.18^{\mathrm{ab}} \pm 0.11$ & $0.48^{\mathrm{b}} \pm 0.10$ \\
Pulp after 12 h fermentation with Bas102 & $4.4^{\mathrm{c}} \pm 0.03$ & $0.40^{\mathrm{ab}} \pm 0.19$ \\
Control pulp after 12 h fermentation & $4.13^{\mathrm{a}} \pm 0.11$ & $0.34^{\mathrm{ab}} \pm 0.03$ \\
Attiéké obtained with Bas 4 & $4.3^{\mathrm{bc}} \pm 0.025$ & $0.021^{\mathrm{ab}} \pm 0.001$ \\
Attiéké obtained with Bas 58 & $4.35^{\mathrm{c}} \pm 0.015$ & $0.024^{\mathrm{b}} \pm 0.006$ \\
Attiéké obtained with Bas 66 & $4.3^{\mathrm{bc}} \pm 0.00$ & $0.016^{\mathrm{a}} \pm 0.003$ \\
Attiéké obtained with Bas 97 & $4.27^{\mathrm{b}} \pm 0.05$ & $0.019^{\mathrm{ab}} \pm 0.001$ \\
Attiéké obtained with Bas102 & $4.29^{\mathrm{bc}} \pm 0.045$ & $0.019^{\mathrm{ab}} \pm 0.001$ \\
Control attiéké & $4.06^{\mathrm{a}} \pm 0.05$ & $0.025^{\mathrm{b}} \pm 0.004$ \\
\hline
\end{tabular}

Data are represented as Means \pm SD (3 replicates). Means in the column with no common letter differ significantly (P<0.05) for each sample.

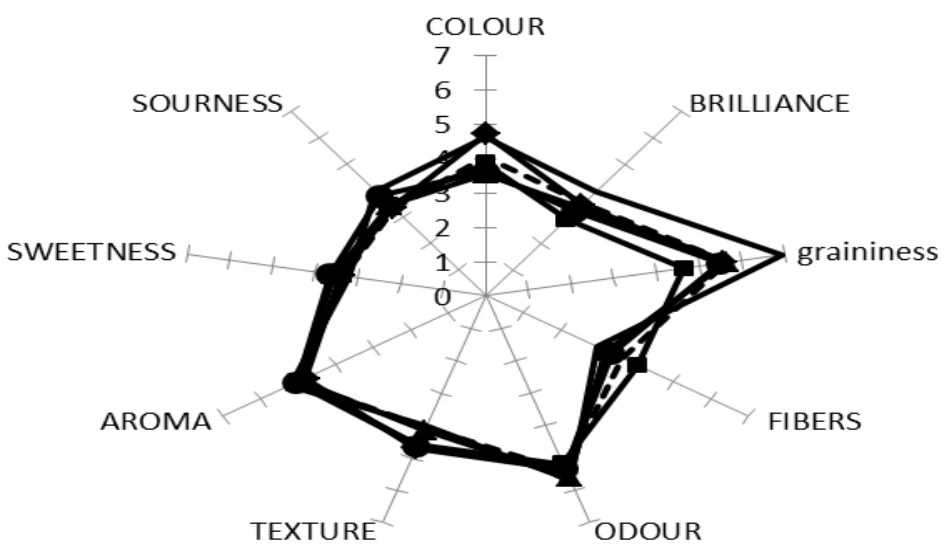

Figure 6 Sensory parameters of different “attiéké” samples

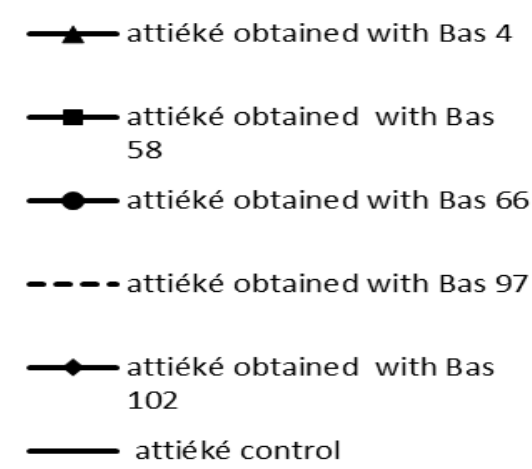


The $\mathrm{pH}$ values of the different "attiéké" samples ranged from 4.27 to 4.35 compared to the control $(\mathrm{pH}=$ 4.06). These results are closed to those of Djeni et al. (2014) ranging from 4.13 to 4.29 for traditional "attiéké" of different towns of Côte d'Ivoire (Abidjan, Dabou and Jacqueville).

From these points of comparison, our results were satisfying, because the sensory test performed by panelists revealed a slightly difference between "attiéké" produced with Bacillus spp. strains and "attiéké" control (traditional "attiéké"). From a general point of view, "attiéké" produced by Bacillus spp. strains was judged acceptable. Furthermore, it is important noting that the synergistic role of Bacillus spp, yeasts and moulds is important for more synthesis of enzymes in order to soften cassava dough inoculated with the traditional starter (mangnan).

\section{Conclusion}

The Bacillus spp. strains isolated from "mangnan" are able to produce lactic acid which is useful for a good fermentation of cassava dough. The production of "attiéké", by using this type of starter (Bacillus spp. strains) highlighted satisfactory results. Therefore, a biotechnological application would be possible, to control and improve the fermentation of cassava dough, in order to obtain a good quality of "attiéké" in Côte d'Ivoire. Before this biotechnological step it would be interesting to quantify enzymatic production (cellulases and pectinases) of Bacillus spp. strains, for a better softening control of the cassava dough.

\section{References}

Aboua F, Kossa A, Konan K, Mosso K, Angbo S, Kamenan A. 1990. Analyse de quelques constituants du manioc au cours de la préparation de l'attiéké. K. Foua Bi and B.J.R. Philomène ed. La post-récolte en Afrique: Séminaire International Abidjan, Côte d'Ivoire, Montmagny QC Marquis Publishers, pp 217-221.

Assanvo JB, Agbo GN, Behi YEN, Coulin P, Farah Z. 2002. la microflore du ferment de manioc pour la production de l'attiéké adjoukrou à dabou (côte d'ivoire). bioterre, revue int SVT, no. Spécial, 286 - 299.

Assanvo JB, Agbo GN, Behi YEN, Coulin P, Farah Z. 2006. Microflora of traditional starter made from cassava for attiéké production in Dabou (Côte d'Ivoire). Food control, 17: 37- 41.

Bokanga M. 2001. Cassava: Post-harvest Operations. Edition International Institute of Tropical Agriculture (IITA). Ibadan: Nigeria, $220 \mathrm{p}$.

Bouatenin KM J P, Djeni TN, Aka S, Brou K, Dje, KM. 2012. The contribution of microorganisms to the fermentation of cassava dough during attiéké processing in Cote d'Ivoire. Glob Scie Book, 6: 58-64.

Coulin P. 2004. Optimierung der fermentativenVerarbeitung von Maniok zu Attiéké durch den Einsatz einer Starterkultur in einem standardisierten Herstellungsverfahren. Thesis, Nr. 15473, Swiss Federal Institute of Technology, Zurich.

Coulin P, Faraha Z, Assanvo J, Spillmann H, Puhan Z. 2006 Characterisation of the microflora of attiéke', a fermented cassava product, during traditional small-scale preparation. Int J Food Microbiol, 106: 131- 136.

Djè KM, Djeni TN, Marie T, Aka S. 2008. Biochimical and Microbiologycal changes of cassava dough fermenting in different temperature condition. J Food Technol, 6: 114-119.
Djeni NT, N'guessan KF, Dadie AT, Dje K M. 2008. Impact of different rates of a traditional starter on biochemical and microbiological changes during the fermentation of cassava for attiéké production. Food, 2: 145- 151.

Djeni NT, N'Guessan K F, Toka D M, Kouame KA, Dje KM. 2011. Quality of attieke (a fermented cassava product) from the three main processing zones in Côte d'Ivoire. Food Res Int, 44: 410416.

Djéni TN, Kouamé AK, Bouatenin JPKM, N'Guessan FK, Dje M K. 2014. Process of attieke production in Côte d'Ivoire: new trends, updates and effects on quality and preference of the food. Int J Adv Res , 2: 644 -653.

Essers S, Bosveld M, Van Der Grift RM. 1993. Studies on the quantification of specific cyanogens in cassava products and introduction of a new chromogen .J Sci Food Agri, 63: 287-296.

FAO. 2008. Why cassava? [Online] Available:http://www.fao.org /ag/agp/agpc/gcds/. Accessed December 22, 2014.

Fortin J, Desmarais G, Assovie O, Diallo M. 1998. L'attiéké couscous de la Côte d'Ivoire. J .Latour ed. Horizon Francophonie, Monde alimentaire, Quebec: Canada, 21: 22 - 24.

Kumar P, Sanjay KSP, Leec JK, Vipin KC . 2013. Extending the limits of Bacillus for novel biotechnological applications.Biotechnol Adv, 31: 1543-1561.

Miambi E, Guyotb,JP, Ampe F. 2003. Identification, isolation and quantification of representative bacteria from fermented cassava dough using an integrated approach of culture-dependent and culture-independent methods. Int J Food Microbiol, 82: 111 - 120.

Mosso K, Aboua F, Gnakri D. 2000. Détoxication en cyanure des aliments dérivés du manioc. Industrie Alimentaire et Agricole, 117: $41-42$.

Nout MJR, Rombouts FM, Havelear A. 1989. Effect of accelerated natural lactic fermentation of infant food ingredients on some pathogenic microorganisms. Int J Food microbiol, 8: 351- 361.

Obadina AO, Oyewole OB, Odusami AO. 2009.Microbiological safety and quality assessment of some fermented cassava products (lafun, fufu, gari). Sci Res Essays, 4: 432- 435.

Obilie EM, Kwaku TD, Wisdom KAA. 2003.Microbial modification of the texture of grated cassava during fermentation into akyeke. Int J Food Microbiol, 89: 275 -280.

Ouattara HG, Ban-Koffi L, Karou GT, Sangare A, Niamke SL, Diopoh JK. 2008. Implication of Bacillus sp. in the production of pectinolytic enzymes during cocoa fermentation. World J Microbiol Biotechnol, 24: 1753-1760.

Ouyang J, Rui M, Zhaojuan Z, Cong C, Min Z, Ting J. 2013. Open fermentative production of L-lactic acid by Bacillus sp. strain NL01 using lignocellulosic hydrolyzates as low-cost raw material. Bioressources Technol, 135: 475 -480.

Oyewole OB. 1992. Cassava Processing in Africa. In: Application of Biotechnology to traditionally fermented foods. Natural Academic Press Washington D. C. P, 90 p.

Penga L, Wanga L, Cheb C, Yangb G, Yua B, Ma Y. 2013. Bacillus sp. strain P38: An efficient producer of Llactate from cellulosic hydrolysate, with high tolerance for 2-furfural. Bioresource Technol, 149: 169 - 176.

Poudel P, Tashiro Y, Miyamoto H, Miyamoto H, Okugawa Y, Sakai K.. 2015. Direct starch fermentation to 1-lactic acid by a newly isolated thermophilic strain, Bacillus sp. MC07. J Ind Microbiol Biotechnol, 42:143-149.

Rosenberg M, Martin R, Ludmila K, Katarina M. 2005. High temperature lactic acid production by Bacillus coagulans immobilized in Lentikats. Biotechnol Letters, 27: 1943 - 1947

Sotomey M, Ategbo E, Mitchipkpe E, Gutierrez M, Nago M. 2001. Innovation et diffusion des produits alimentaires en Afrique: l'attiéké au Bénin, Dans "alimentation, savoir-faire et innovations en agroalimentaire en Afrique de l'Ouest». Ed CIRAD, 6: 1- 91 . 
Sow NML. 2004. Selection Et Caracterisation De Bacteries Lactiques D'origine Africaine En Vue D'une Utilisation Comme Probiotiques, Dissertation originale présentée en vue de l'obtention du grade de docteur en sciences agronomiques et ingénierie biologique, $216 \mathrm{p}$.

Toka MD, Djeni TN, Dje MK. 2008. Improved Process of Cassava Processing into "Attiéké", a Traditional Food Product of Côte D’Ivoire. Int J Food Eng, 4: 1 - 13.
Weagant SD, Feng P, Stanfield JT. 2001. Yersinia enterocolitica and Yersinia pseudotuberculosis. In: Bacteriological Analytical Manual Online. US Food and Drug Administration, Center for Food Safety and Applied Nutrition http://www.cfsan.fda.gov/.

Yao AAS, Brou K, Nevry RK, Djè KM. 2013. Microbiology of Ivorian Fermented Products. Asian J Agri Food Sci, 1: 37 -47. 